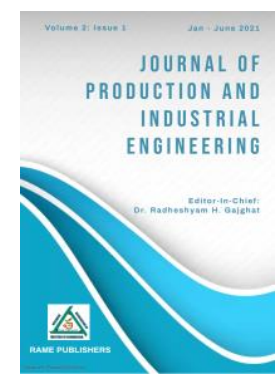

Obed John Dagwa Johnobed74@gmail.com

University of Maiduguri, Borno State, Nigeria.

\title{
Automated transmission of hand water pumps in remote towns of Nigeria: Attaining a sustainable development project management
}

Abstract - This paper examines the rational that causes the huge failure of hand water pumps in remote towns from an automated transmission perspective, by looking at the already existing hand water pump automation transmission procedures in Nigeria where over 5,000 hand pumps were installed and about $70 \%$ are not working. This paper examined the lack of a well-structured and sustainable knowledge sharing practices within the main stakeholders, community users, and the government. It was analyzed that maintenance and operations, and the integration of a project management strategy were requisite criteria for the sustainability of the hand water pump in the remote towns' water supply project. Community users have minimum involvement throughout the project phase; they have no knowledge on the technical approach of accessing the failed parts, the community does not have a trained expert to work on it and the government does not reserve spare parts of the equipment. The communication between the remote users and the suppliers is very poor which contributes which also leads to problems. Therefore, it is necessary to have a strategic focus on allocation of resources for automation transmission process. There is need for a model of maintenance which results from the objective of the study to provide for practical coordination that integrates both major stakeholders. The objective is to establish an institutional and sustainable support system through various partnerships.

Keywords - Remote Towns, Automated Transmission, Hand Water Pump, Sustainable Development, Project Management.

\section{INTRODUCTION}

Hand water pumps are commonly used for water supply in remote towns in Africa, and it currently has over 350,000 installed hand water pumps. The UNICEF published a data that showcases about 150,000 hand water pumps were dumped. The manual pump failure rate in dry and remote areas is more than $80 \%$ [1]. In $2005,35 \%$ of all rural water supplies were not operational in sub-Saharan Africa [2]. 39

Technical Article - Peer Reviewed

Published online - 26 January 2021

\section{(C) 2021 RAME Publishers}

This is an open access article under the CC BY 4.0 International License https://creativecommons.org/licenses/by/4.0/

Cite this article - Obed John Dagwa, "Automated transmission of hand water pumps in remote towns of Nigeria: Attaining a sustainable development project management", Journal of Production and Industrial Engineering, RAME Publishers, vol. 2, issue 1, pp. 13-18, Jan 2021. https://doi.org/10.26706/jpie.1.2.20200802 percent were not operational, 19 percent were partially operational, and the International Relief and Development (IRD), a Non-Governmental Organization, carried out in 2009 on 425 boreholes in southern Swaziland. [3]. Statistics across the world, especially in developing countries, indicate that rural water supply facilities are falling out of use at an alarming rate [4]. With this data, there is an immediate need to adopt a different strategy on looking at the threats affecting the sustainability of borehole hand pumps. An important aspect in the project management of automation is the appropriate transmission of that automation to the remote community users through the procedure of automation transmission. To address the low sustainability of hand water pumps in the remote towns of Nigeria, it is important to study the problem of transmitting the automation from the 
industrial producers of the hand water pumps to the users in the remote towns. This research examines the rationale behind the huge rate of failed hand water pump in the entire context of automation transmission by looking into the already existing practice in Nigeria, where the only source of water is mostly the hand water pump.

\section{A. Automation Transmission}

Automation Transmission is a process in which a technology provider transmits and communicates the technology to the receiver through several activities and eventually enhances technological capabilities of the receiver [5]. Automation transmission encompasses more than equipment and other hard technologies, for it also includes entire systems and their component parts, 'knowhow', goods and services, equipment, and organizational and managerial procedures [6]. The transfer of technology therefore involves both "hard" and "soft" technology. In developing countries, a narrow definition was adopted for the transfer of hard technology and subsequently hard technology overridden training, institutional capacities, and infrastructure. All these conditions are necessary for the maintenance of hard technology [7]. Looking at the context of hand water pump automation transmission, appropriate modern automation selection through suitable participation of users, knowledge management, maintenance and operation plans, technology improvement through feedback, and research and development are all important factors for sustaining hard technology.

The sustainable use of hand water pumps in remote town has been received a huge setback following factors that relates to the supply and demand. Considering the low capacity of the remote town dwellers to purchase hand water pump equipment, there is little incentive for the private industry to hugely invest in the design and production of the hand water pump. Contribution factors from the demand side include: lack of adequate operational and maintenance support from the institution; lack of mechanism for funding that often depend on the funding of donors; inadequate technical support for maintenance training; and lack of participation in the community[8-13]. The lack of plans and expertise in project management has also adversely affected project success [7].

As the automation transmission is process where the hard and soft component of the automation is transferred from the supplier to the remote user, it requires a strategic approach for transmission to be successful. This approach is the project management.

\section{B. Sustainable Project Management}

Existing literature explained sustainability in 3 phases which involves environmental, social and economic prospect. Hence, sustainability encompasses keeping human development in the three dimensions, which often referred to as sustainable development [14]. Life-cycle technique evaluates the environmental impact of a product, process or service at the design phase, whereas Life cycle management is an extension of the Life-Cycle Engineering (LCE) concept, namely the product, process, and service life cycles that are managed after the design phase [15]. Further argue that a holistic LCM approach requires an effective integration of the three life cycles (projects, assets and products) for organization.

\section{Sustainability of Hand Water Pump}

Hand water pump-equipped boreholes are the most common and frequent water supply automation used in remote towns of Africa, but it has a very low sustainability level. This high failure rate is mainly due to lack of consideration for the operation and maintenance of the pump and consequently a low sustainability [8]. Additional reasons include poor financial management[9], technology mismatch, the water environment and the system maintaining capacity of users[11] and the borehole failures[16]. Sustainability frameworks, approaches and initiatives for rural water supply can be found in the literature. The three basic sustainability components proposed by Montgomery et al..[12]: (1) effective community demand; 2) local financing and cost recovery; and (3) dynamic operation and maintenance. The allowing factors, together with the main obstacles and problem shooting approaches were presented for each of these 
components. [8] Eight key sustainable factors have been identified. These are: policy context, institutional arrangements, economic and financial issues, Community and social aspects, technology and the natural environment, supply of spare parts, maintenance and monitoring. These individual factors, together with guidance on sustainability, were explored extensively in relation to financing, effective demand and management.

In combination with the experience of authors in this field, remote water supply service failures are due to two broad aspects with these observations in literature reviews:

Technical: Failure relating to the design and construction of the borehole, pump selection type and procedure and the lack of replacement parts.

Managerial: These are failures linked to poor local administration and inefficient systems of support (financial, operational, and management).

It is evident that the cause of the failure in hand water pump could be technical or managerial. Analyzing the gaps of automation transmission from these prospects is imminent.

\section{Research Aim}

This research paper aimed to evaluate the ideal issues related to transmission of hand water pump in remote towns of Nigeria and other nations and also analyze the causal issues of hand water pump failures with recommended solutions to enhance its efficiency and sustainability. This paper also tries to enhance the relationship between the users and suppliers and how automation transmission can be passed across to the users.

\section{E. Scope and Importance of Study}

The research analysis of 32 hand water pumps has scope in present and future. This research will eliminate all the problems associated with the present situation of automating hand washing pumps in remote communities of Nigeria. This research has high cost, high time consuming and will be an important government and nongovernmental tool in achieving their requisite target towards automating the hand water pumps.

\section{Methodology}

The research methodology used is the mixed methods, namely qualitative and quantitative methods of data collection and analysis. A mixed methods approach attempts to take advantage of the similarities and differences in qualitative and quantitative methods [17]. The research population that was selected for the case study is are funded by International Organization for Migration located in Borno State. For the hand water pump users, from a sample of 70 borehole sites in IOM areas of operation, 32 boreholes were selected through multi-stage, systematic random sampling in 6 remote towns of Borno State which are: Bama, Gwoza, Chibok, Mafa, Damboa, Dikwa, Local Government Areas respectively. A questionnaire was administered to 73 users who source water from the 32 boreholes; $93 \%$ of them were regular members of the towns. The selection of hand water pump for the research were based on the relative distribution of the pump sizes. Information was collected from key informants from International Non-Governmental Organizations (INGOs), Government agencies, pump manufacturers and other stakeholders in the provision and use of hand pumps in Nigeria.

\section{Discussion AND RESUlt}

The hand water pump usability and efficiency differ with various brands from suppliers. Also, some hand water pumps are frequently used more than others. This result to the breakdown and malfunctioning of major hand water pumps. Further research indicates that some of the boreholes have no sufficient water in it, thus making the hand water pump useless in the static position. The malfunctioning of the hand water pump is due to the design, operational and maintenance of the instrument. Other research and papers have supported this claim, as [8] asserts that the primary reason for hand pumps failure is insufficient attention to the operation and maintenance. 


\section{A. Hand Water Pump Sources}

In the remote towns in Nigeria, the hand water pumps were Holland for the Blue Pump and India for the India Mark 2 and the Afridev pumps. The Afridev and the Indian Mark 2 pumps were introduced in the remote towns of Nigeria following the water crisis outbreak by humanitarian organizations. Popularly, the system of water supply is the well and stream. Recently the Blue Pump was introduced through the International development organizations following the conflict that emanated in the nation that ravaged the local towns. Careful selection of the type of hand water pump is crucial to the sustainability of the hand water pump. Table 1 summarizes advantages and disadvantages of the major pumps in remote towns of Nigeria based on the gathered information.

TABLE 1

COMPARISON OF HAND WATER PUMPS FROM FIELD ASSESSMENT

\begin{tabular}{|c|c|c|}
\hline $\begin{array}{l}\text { Pump } \\
\text { Type }\end{array}$ & Advantages & Disadvantages \\
\hline Afridey & $\begin{array}{l}\text { - Easy installation and } \\
\text { repair } \\
\text { - Cheaper than others } \\
\text { - Suitable for wells with } \\
\text { shallow depth }\end{array}$ & $\begin{array}{l}\text { - Not suitable for deep } \\
\text { wells } \\
\text { - It requires frequent } \\
\text { maintenance } \\
\text { - Being a public domain } \\
\text { pump, it's difficult to } \\
\text { maintain }\end{array}$ \\
\hline $\begin{array}{l}\text { Indian } \\
\text { Mark II }\end{array}$ & $\begin{array}{l}\text { - Best for deep wells } \\
\text { - Very costly }\end{array}$ & $\begin{array}{l}\text { - Installation and repair } \\
\text { require expertise }\end{array}$ \\
\hline $\begin{array}{l}\text { Blue } \\
\text { Pump }\end{array}$ & $\begin{array}{l}\text { - Suitable for both } \\
\text { shallow and deep wells } \\
\text { - Easy to install } \\
\text { - Low maintenance cost }\end{array}$ & - Very costly \\
\hline
\end{tabular}

\section{B. Automation Transmission}

i. Equipment Enhancement: The research proves that there is limited funding from government and INGOs and the feedback between suppliers and users is very limited.

ii. Knowledge transmission: The research indicated that the attention provided to the knowledge transmission, particularly the soft technology, is insufficient. The time is inadequate for the users during training. A day training session is usually provided to water point rural town executive during pump installation, and it usually involves the "How" part of operation and management, and less emphasis is placed on the "Why". There are no user-friendly hard back manuals left behind with the users, to which they can refer during the operation of the hand pumps.

iii. Preferred Pump Selection: The majority of the pumps breaking down in the remote towns were Afridev pumps. The survey also indicated that the average borehole depth is 72 meters, which is beyond the capacity of Afridev pumps.

This research also examined the automation barrier transfer that includes:

- Most hand pumps are exported from various nations and the suppliers are not in contact with the remote users.

- The remote communities believe it is the duty of the government to protect and manage the hand water pumps.

\section{Project Management}

The selection of automation is entirely adopted by implementers, so only a single automation choice is given to the users, namely hand water pumps. The type of hand water pump selection is done only by the implementing agencies. Training on the hand water pump management for the representatives of the communities is provided using the supplier's manual, which is not adequate in itself. In the current arrangement, the responsibility for operational management lies on the town users for minor repairs and the rural water supply branch of the Government for major repairs. However, all INGOs that were interviewed agree that the current hand water pump management practice do not meet their satisfaction. It looks as if the product support, knowledge and project management issues have not been given the required attention by both suppliers and implementing agencies. This applies to any phase of the product or project management, which has immensely contributed to hand water pump failures. 


\section{Maintenance of Hand Water Pumps}

The biggest factor of a failed hand water pump is the issue of maintenance. The provision of appropriate funding mechanisms is much needed for the remote towns to manage the facilities themselves. For the sustainability of the system the importance of user payment for the service has been highlighted [7]. Although, water, is a basic necessity for every living creature, both human and animal. Seasonal variations in water provision also mean that the economic ability of communities to pay for the service changes over time. Of the respondents, over $92 \%$ indicated that when their hand water pump got spoilt, they do not have an alternative to repair or replace. The focus of the INGOs and Government was on the formation of the WASH sector without providing the remote dwellers with any training and management of the entire project. If the towns are not properly equipped and trained with the requisite knowledge, there will be a huge problem in the effective management of the hand water pump.

\section{CONCLUSION AND RECOMMENDATION}

Due to the recent automation advancement, it is certain that the production of the hand water pump can take a dimension which can be easy to install, operate and maintain. Also, the cost should be less compared to the current high cost of purchase, installation and management as seen in some remote towns. Achieving this objective is the commitment of the government, other donor agencies and INGOs. Government and donor agencies have invested hugely into the purchase and management of the hand water pumps in these remote towns. Looking critically, these investments can be channel through research and development of a better-quality hand water pump which can be easily managed and repaired by the locals when it developed an issue. The investment in the design and production can reduce the high cost which would in turn contribute significantly to maintenance cost.

\section{A. Maintenance}

This strategy aims to analyze the gaps and possible remedy to the problems in automation transmission and sustainability of the hand water pumps in remote towns of Nigeria. It addresses the key issues of water sustainability, knowledge management and system project management. The proposed maintenance model aims to aid government and donors in planning, developing and implementing a support system by coordinating and sharing knowledge between stakeholders.. The model is therefore to be utilized by all stakeholders to assist in the development and provision of hand water pump services to the remote towns.

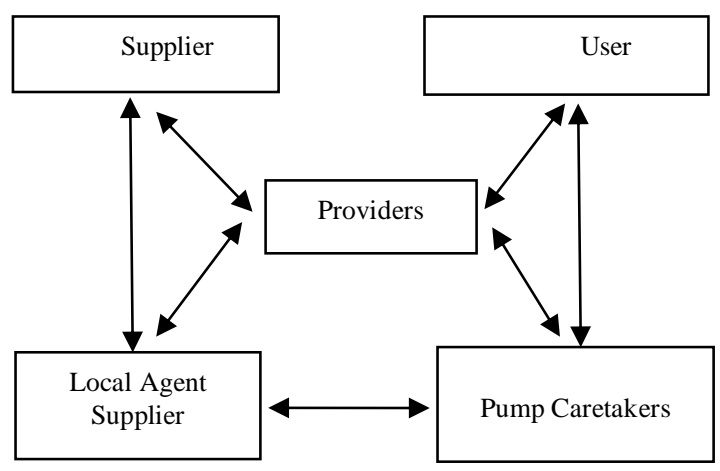

Figure 1. Showcasing a hand water pump maintenance system.

The hand water pump caretakers are a remote based firm situated in the local community which tasked is strictly to operate and manage the hand water pump system for the remote town. The concept is that the local town will sign a memorandum of understanding with firm for operation and subsequently enroll selected members of the town on how to fully operate the pump. Government and Donor agencies through their implementing partners will also sign an agreement on behalf of the local town.

The suppliers take the responsibility of making sure that, there is a support system and also a maintenance policy of the hand water pump.

The local supply agent should ensure that all parts of the hand water pump are available all the time. And the local supply agent should ensure to establish and consistent communication always between all stakeholders and the caretakers.

Providers are the government and INGOs. In other cases, some NGOs also are part of them with funding from donor agencies. These providers should lead in the entire system of ensuring the cost of maintenance and training of locals. 
The user is keenly responsible for the operation of the hand water pump. They need to be trained in order to ensure safe an efficient use of the hand water pump system.

\section{B. Hand Water Pump Sustainability}

i. Hand water pump producers' needs to improve the quality of their products by engaging users through feedbacks.

ii. The hand water pump producers should work with implementing agencies to establish product support systems.

iii. Before purchase of hand water pumps, it should be standardized.

There has to be an appropriate funding policy and it should be managed by the Water, Sanitation and Hygiene sector which allow flexible operation of the entire scheme in accordance with the laid and agreed principles.

\section{ACKNOWLEDGMENT}

The author expresses gratitude to the local officials in the remote towns of Borno, Yobe and Bauchi State. The author wishes to thank the respondents, INGOs, government agency and the hand water pump local manufacturers for their contributions.

\section{REFERENCES}

[1] Fairwater Foundation. "Fairwater cares about water and environment", http://www.watsan.com.htm; [accessed 12.04.03], 2010.

[2] Baumann E. "Common RWSN context, Discussion Paper." St. Gallen, SKAT/RWSN; 2005.

[3] IRD. "Borehole mapping in the Lowveld of Swaziland." IRD Swaziland: Unpublished; 2009.

[4] Phakhati M., "More boreholes, no water." Inter Press Service, http://ipsnews.net/news.asp?idnews=49037; [accessed 12.04.02], 2009.

[5] Wang W, Lee A., "An evaluation framework for technology transfer of new equipment in high technology industry." Technological Forecasting \& Social Change; 77: 135-150, 2010.
[6] United Nations Environmental Programme (UNEP). "Technology transfer: The seven 'C's for the successful transfer and uptake of environmentally sound technologies." International Environmental Technology Centre UNEP, Osaka, Japan; 2003.

[7] Mabuza L, Brent AC, Mapako M. The transfer of energy technologies in a developing country context - Towards improved practice from past successes and failures. Proceedings of World Academy of Science, Engineering and Technology; 22: 237-241, 2007.

[8] Harvey P., Reed R., "Rural water supply in Africa: Building blocks for sustainability." Loughborough University, UK: Water, Engineering, and Development Centre (WEDC); 2004.

[9] Haysom A., "A study of the factors affecting sustainability of rural water supplies in Tanzania." Bedfordshire, UK: Cranfield University; 54, 2006.

[10] Heikkila T., Stellar D., Silva F., Filho F., Tress S., Lall U., "Designing sustainable and scalable rural water supply systems; Evidence and lessons from northeast Brazil.” Earth Institute, Columbia University, http://water.columbia.edu; [accessed 12.03.22], 2012.

[11] Hunter P.R., Macdonald A.M., Carter R.C., "Water supply and health." PloS Med; 7(11): e1000361, 2010.

[12] Montgomery M.A., Bartram J., Elimelech M., "Increasing functional sustainability of water and sanitation supplies in rural sub-Saharan Africa." Environmental Engineering Science; 26(5): 1017-1023, 2009.

[13] Mackintosh G. Colvin C., "Failure of rural schemes in South Africa to provide potable water." Environmental Geology; 44: 101-105, 2003.

[14] Ciceri N.D. Garetti M. Terzi S., "Product lifecycle management approach for sustainability." Proceedings of the 19th CIRP Conference - Competitive Design, Cranfield University; 30-31: 147, 2009.

[15] Labuschagne C. Brent A.C., "Sustainable Project Life Cycle Management: The need to integrate life cycles in the manufacturing sector." International Journal of Project Management; 23 (2): 159-168, 2005.

[16] Harvey P., "Borehole sustainability in rural Africa: An analysis of routine field data." 30th WEDC International Conference, Vientiane, Lao PDR; 339-346, 2004.

[17] Yin R.K., "Qualitative research from start to finish." The Guilford Press New York London; 2011. 